\title{
Agrobacterium radiobacter
}

National Cancer Institute

\section{Source}

National Cancer Institute. Agrobacterium radiobacter. NCI Thesaurus. Code C86137.

A species of Gram negative, rod shaped bacteria assigned to the phylum Proteobacteria.

This bacteria is motile, non sporeforming, oxidase and catalase positive, hydrolyzes

esculin and ferments glucose, xylose and mannitol. A. radiobacter is commonly found in soil and is an opportunistic pathogen in humans. 